\title{
A new Plotosaurini mosasaur skull from the upper Maastrichtian of Antarctica. Plotosaurini paleogeographic occurrences
}

\author{
Pablo González Ruiz ${ }^{\text {a, * }}$, Marta S. Fernández ${ }^{\text {b }}$, Marianella Talevi ${ }^{c}$, Juan M. Leardi ${ }^{\text {d, e }}$, \\ Marcelo A. Reguero b, f \\ a CONICET, Grupo vinculado del IANIGLA, Museo de Historia Natural de San Rafael, Parque Mariano Moreno s/n, M5602DPH, San Rafael, Mendoza \\ Argentina \\ b CONICET, División Paleontología Vertebrados, Unidades de Investigación Anexo Museo, Facultad de Ciencias Naturales y Museo, UNLP, Av. 60 y 122, \\ B1900AVW, La Plata, Argentina \\ ${ }^{c}$ CONICET, Instituto de Investigación en Paleobiología y Geología (UNRN-CONICET), Av. Roca 1242, R8332EXZ, General Roca, Río Negro, Argentina \\ d CONICET, Instituto de Estudios Andinos "Don Pablo Groeber" (UBA-CONICET), Departamento de Ciencias Geológicas, Facultad de Ciencias Exactas y \\ Naturales, UBA, Intendente Güiraldes 2160 Ciudad Universitaria - Pabellón II, C1428EGA, CABA, Argentina \\ e Departamento de Biodiversidad y Biología Experimental, Facultad de Ciencias Exactas y Naturales, Universidad de Buenos Aires, Argentina \\ ${ }^{\mathrm{f}}$ Instituto Antártico Argentino (Dirección Nacional del Antártico), 25 de Mayo 1143, San Martín, Argentina
}

\section{A R T I C L E I N F O}

\section{Article history:}

Received 12 September 2018

Received in revised form

21 May 2019

Accepted in revised form 19 June 2019

Available online 3 July 2019

\section{Keywords:}

Upper cretaceous

Marambio Island

Antarctic Peninsula

Mosasaur

\begin{abstract}
A B S T R A C T
During the Antarctic summer campaigns and as a result of paleontological fieldworks 2013-2015 several mosasaur remains have been collected from the upper Maastrichtian López de Bertodano Formation exposed at Marambio (=Seymour) Island, of the Antarctic Peninsula. One of these specimens preserves part of the skull and dentition, which represent one of the few known skulls from Antarctica. The new specimen (MLP 15-I-24-41) is similar to member of the mosasaur tribe Plotosaurini, sharing the same fronto-parietal suture pattern, and a similar dental morphology as some of the species assigned to the genus. As the specimen is not complete enough to propose a new name it is referred to Mosasaurus sp. The presence of these remains on the southern hemisphere represents one of the most complete records of a Mosasaurus mosasaur.
\end{abstract}

(c) 2019 Elsevier Ltd. All rights reserved.

\section{Introduction}

Mosasaurs were a very successful group of marine reptiles that invaded the marine realm during the late Cretaceous period and developed a fully marine lifestyle (Polcyn et al., 1999, 2003, 2014). The earliest records of mosasaur remains belong to the Cenomanian of Israel (Polcyn et al., 1999), while the youngest ones have been recovered from various Maastrichtian deposits around the world (Mulder et al., 1998; Kiernan, 2002; Gallagher, 2005; Martin, 2006; Fernández et al., 2008; Bardet et al., 2014; Fernández and Talevi, 2015; Milàn et al., 2017).

Mosasaurus Conybeare 1822 is one of the most frequent and widespread taxa, with a life history that extends from the Campanian up to the late Maastrichtian (Polcyn et al. 2014; Street and

\footnotetext{
* Corresponding author. CONICET, Museo de Historia Natural de San Rafael, Parque Mariano Moreno s/n, M5602DPH, San Rafael, Mendoza, Argentina.

E-mail addresses: pgonzalez@mendoza-conicet.gob.ar (P. González Ruiz), martafer@fcnym.unlp.edu.ar (M.S. Fernández), mtalevi@unrn.edu.ar (M. Talevi).
}

Caldwell, 2016). Fossils referred to this genus have been reported in all continents including Antarctica (Fernández and Gasparini, 2012). The taxonomy and diversity of its type species, Mosasaurus hoffmannii Mantell (1829), has been recently clarified. Street and Caldwell (2016) provided a detailed description and an emended diagnosis, providing a robust basis for comparison and identification of fossils referred to this taxon, and reviewed the validity status of the different species referred to this genus.

In the past 30 years, collaborative paleontological expeditions to the Antarctic Peninsula have been carried out by the staff of the Museo de la Plata (Universidad Nacional de la Plata, Argentina) and the Instituto Antártico Argentino (IAA) during summer field seasons (Campañas Argentinas de Verano, CAV's). Particularly, late Maastrichtian levels of the López de Bertodano Formation (Rinaldi et al., 1978; Macellari, 1988; Olivero, 2012), outcropping at Marambio (=Seymour) Island, have yielded significant amount of marine reptiles, including several mosasaur remains mainly referred to the Mosasaurines (Gasparini and Del Valle, 1980, 1984; Martin et al., 2002; Martin, 2006; Fernández and Gasparini, 2012). 
However, up to date, most of these remains correspond to postcranial elements and/or isolated teeth. An exception is a fragmented skull and humerus recently described as the new tylosaurine Kaikaifilu hervei (Otero et al., 2016).

In the present contribution, we describe a new specimen, recovered during the CAV 2015, from the López de Bertodano Fm. (Marambio Island, Antarctica) identified as Mosasaurus sp.. This new discovery represents one of the few, bigger and most complete Mosasaurus skulls from Antarctica for the upper Cretaceous.

\section{Geological setting}

The studied material was collected on the upper levels of the López de Bertodano Formation (Rinaldi et al., 1978) that outcrops on the central part of the Marambio (=Seymour) Island, Antarctica (Fig 1). The age of the formation was first assigned to Maastrichtian-Paleocene age based on mollusks (Zinsmeister, 1979, 1982; Zinsmeister and Macellari, 1988), microfossils (Huber, 1988) and palynomorphs (Askin, 1989). Later on, the age was further constrained to the Maastrichtian-early Danian (Olivero, 2012). The López de Bertodano Formation (LBF) beds on Marambio Island are dominated by silt, with varying components of sand and clay, and have been interpreted as deposited on an open shelf, in water depths ranging from 10's of meters to $200 \mathrm{~m}$ (Macellari, 1988). Macellari (1988) divided the LBF ten informal units into two separate groups, the lower "Rotularia Units" (LB2-LB6), and the upper "Molluscan Units” (LB7-LB10). The lowest unit (LB1) has been redefined as the Haslum Crag Sandstone (Snow Hill Island Formation) (Olivero et al., 2008; Olivero, 2012). Depending on the base of the section used and the particular study, this interval represents about 1100 stratigraphic meters, with approximately the lower $\sim 600 \mathrm{~m}$ corresponding to the Rotularia Units, and the iridium anomaly representing the K-Pg boundary located at the lithologically defined LB9-LB10 boundary (Elliot et al., 1994). Molluscan fossils are much less common in the Rotularia Units (which are dominated by fossils of the worm Rotularia) than the Molluscan Units, though they are not absent. Overall, water depth increases from possibly estuarine in the lower units to fully open shelf in the upper units (Olivero, 2012).

The studied specimen has been recovered from the LB9 unit close to the K/Pg event zone at coordinates S $64^{\circ} 16^{\prime}$; W $56^{\circ} 44^{\prime}$.

\section{Materials and methods}

The specimen described herein (MLP 15-I-24-41) was mechanically prepared at the Museo Nacional de la Plata (Argentina). Since the rock matrix was hard and the fossils were deeply embedded into it, a conjunction of chemical consolidates (Paraloid B-72) and pneumatic air scribes were used to separate most of the matrix from the fossils. Due to the matrix constitution and fossil fragility of some elements, the specimen was not completely prepared to prevent the breakage and disarticulation of these elements.
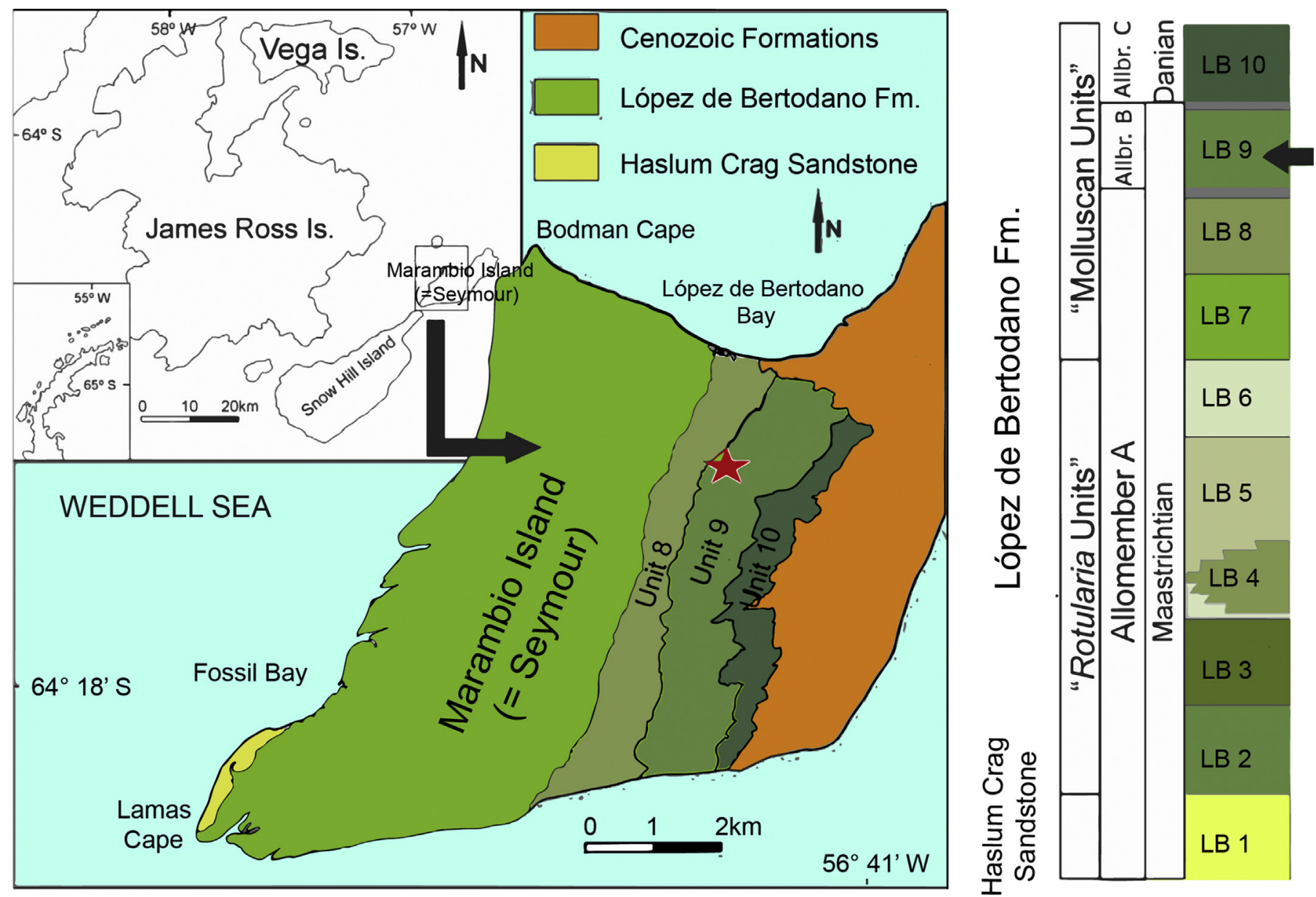

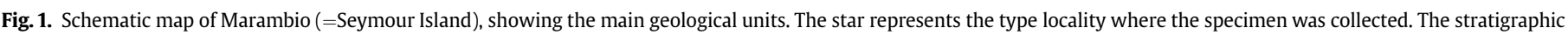
position of MLP 15-I-24-41 is shown on the right side (Taken and modified from O'Gorman et al., 2017). 


\subsection{Institutional abbreviations}

Institutional abbreviations used on this contribution are: MLP Museo Nacional de la Plata, Buenos Aires province Argentina, MML Museo Municipal de Lamarque, Rio Negro province, Argentina MNHN Muséum national d'Histoire naturelle, Paris, France.

\section{Systematic paleontology}

Class REPTILIA Linnaeous, 1758

Order SQUAMATA Oppel, 1811
Family MOSASAURIDAE Gervais, 1852

Subfamily MOSASAURINAE Gervais, 1852

Genus Mosasaurus Conybeare, 1822

Species Mosasaurus sp.

Referred specimen. MLP 15-I-24-41, a partial skull including, partial frontal, right postorbital, parietal, right quadrate, right posterior end of basisphenoid, right coronoid, right angular, splenial and right surangular, a broken marginal tooth and several pterygoid teeth have been associated to this specimen.
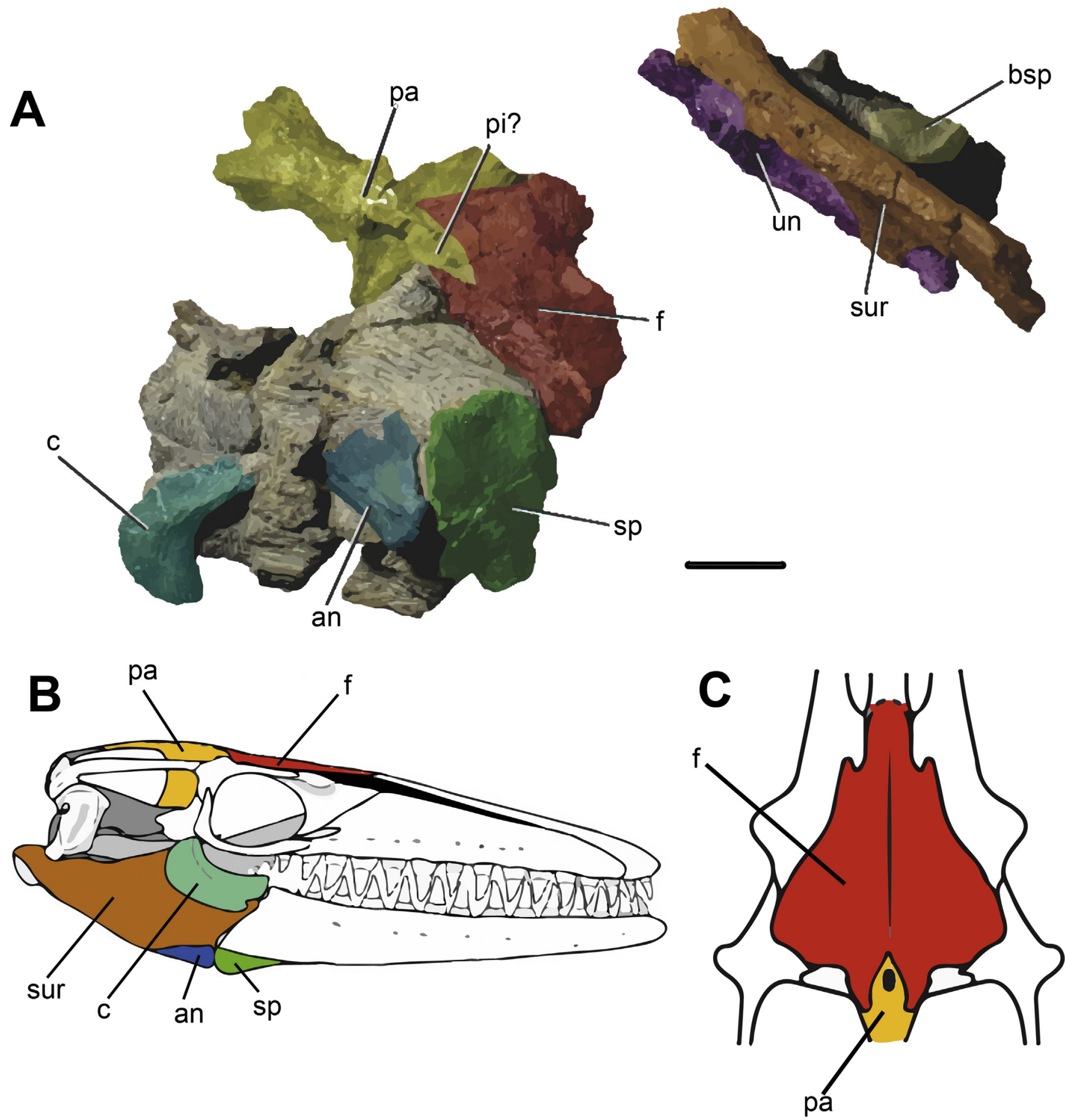

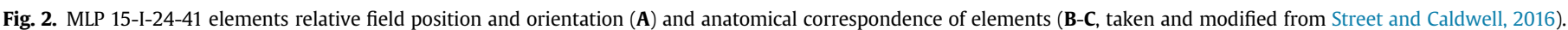

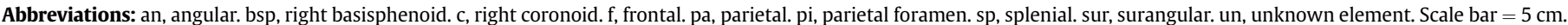


Locality and horizon. MLP 15-I-24-41 was recovered from the upper Maastrichtian LB9 unit from the Lopez de Bertodano Fm. at Marambio Island, Antarctica.

General considerations. (Fig. 2) MLP 15-I-24-41 was recovered as a single block with elements embedded on the matrix. Disarticulated vertebrae and teeth were also found in close proximity to the specimen. After mechanic preparation, many elements were isolated from the matrix while some others were kept enclosed in it because further preparation was hindered by the sediment consistency and risked damage of the elements preserved. Schematic illustrations of the preserved elements are shown in fig. 2(B-C) over a reconstruction of a mosasaur skull.

Frontal. (Fig. 3A-D) The frontal is incomplete, preserving only its posterior end, including the fronto-parietal suture. Its right side is mainly covered by the matrix and by a displaced portion of the right splenial. Along its midline, both right and left sides are separated on the anterior end, and a well-developed sagittal crest is observed on its dorsal surface (Fig. 3A-B).

The posterior margin forms the fronto-parietal suture. The frontal projects two prongs that overlap over the parietal and embrace a region that bears the parietal foramen. The prongs are asymmetrical, thick medially and thin out posteriorly (Fig. 3A-B). The lateral contact between the parietal ala and the frontal is not straight and seems to be slightly curved.

Ventrally, the frontal has a deep sagittal groove that is bounded by a ridge on each side, the cristae cranii, forming the olfactory canal (Fig. 3C-D). Both the parietal and the postorbital articulate on the ventral surface. The postorbital articulation occupies a large area of the posterior end of the frontal. The parietal articulation ventrally is more complex. The parietal ala contacts with both the frontal and the postorbital. Medially the parietal underlies part of the frontal process of the postorbital and projects anteriorly. This anterior projection of the parietal is broken and its extension is not measurable.

Postorbitofrontal. (Fig. 3C-D) Of the right postorbitofrontal, only the frontal articulation process is preserved. It is found on the ventral surface of the frontal. It has a flat square-like shape and contacts posteriorly with the parietal.

Parietal. (Fig. 3E-F) The parietal preserves most of its anterodorsal portion. On its dorsal surface, the parietal slightly thins out toward its posterior end until it reaches the suspensory ramus divergence point. At this point, the ramus diverges laterally and the overall shape thickens once again. This second thickening never reaches the width of the anterior portion.

Anteriorly, the parietal is overlain by the frontal prongs close to the midline. The parietal then follows the frontal's outline forming the parietal ala of which only the left one is preserved on articulation with the frontal. The parietal foramen is not recognizable due to preservation, but it seems to be located between the frontal prongs. The lateral edges of the parietal table are sharp and form shelves that overhang the descending process of the parietal. The edges are almost parallel to each other until the divergence point.
A
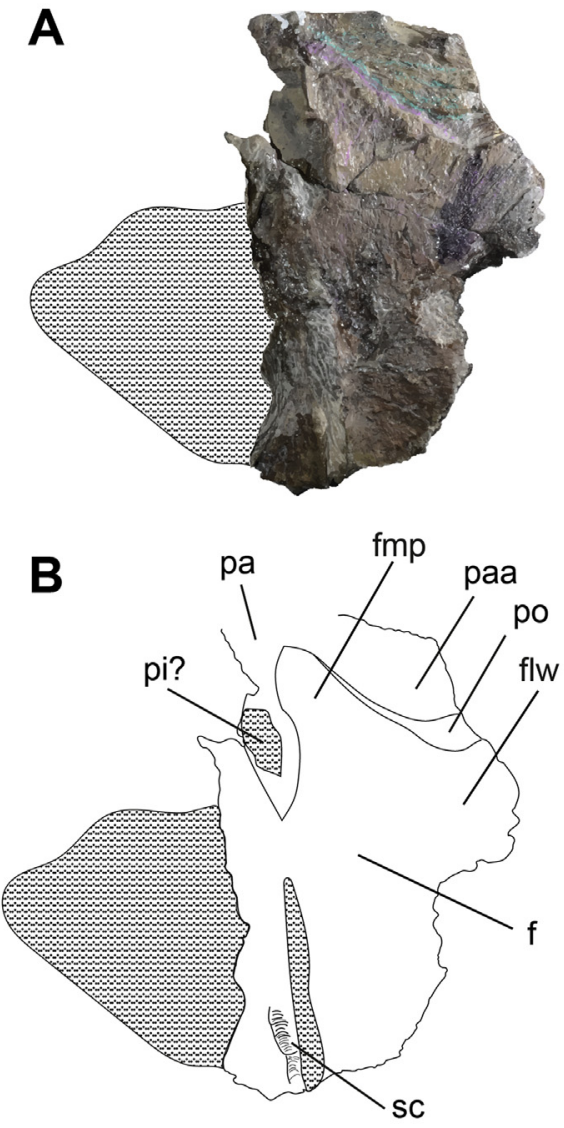

Broken surface

\section{C}

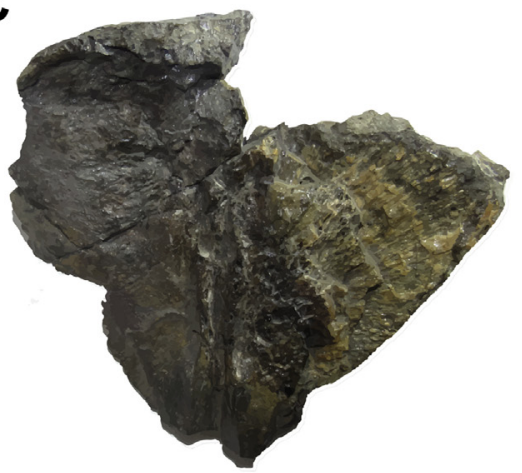

D

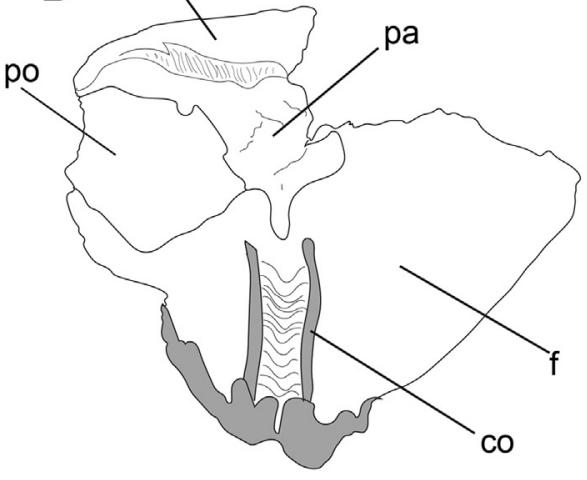

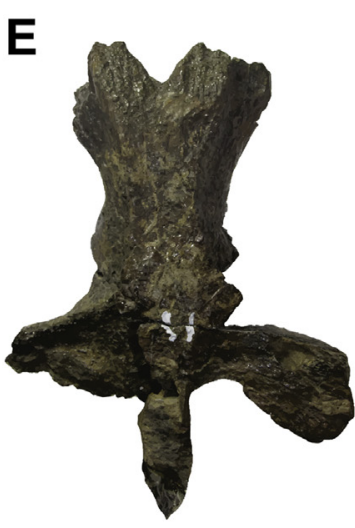

F

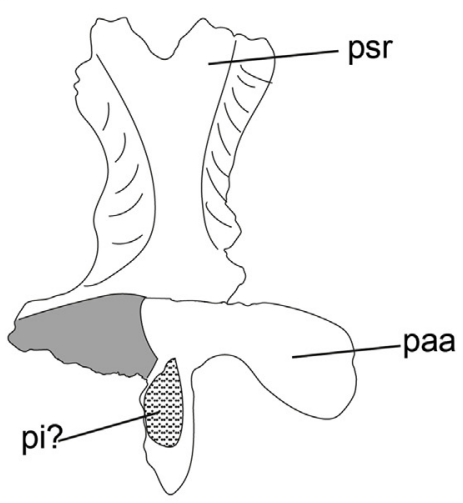

\section{Sediments}

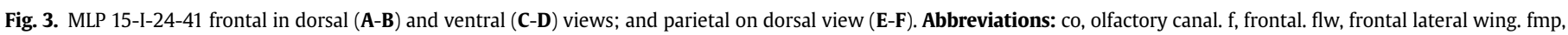
frontal medial prongs. pa, parietal. paa, parietal ala. pi, parietal foramen. po, postorbitofrontal. psr, parietal suspensory ramus. $\mathrm{sc}$, sagittal crest. Scale bar $=5 \mathrm{~cm}$. 


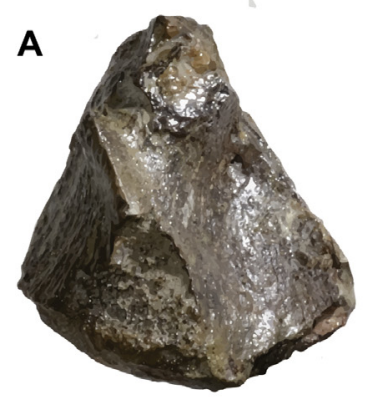

\section{c}

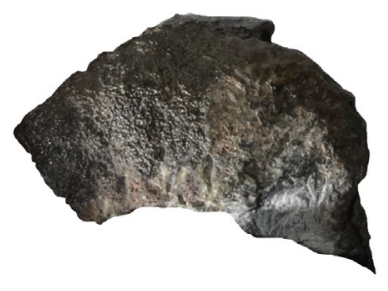

D
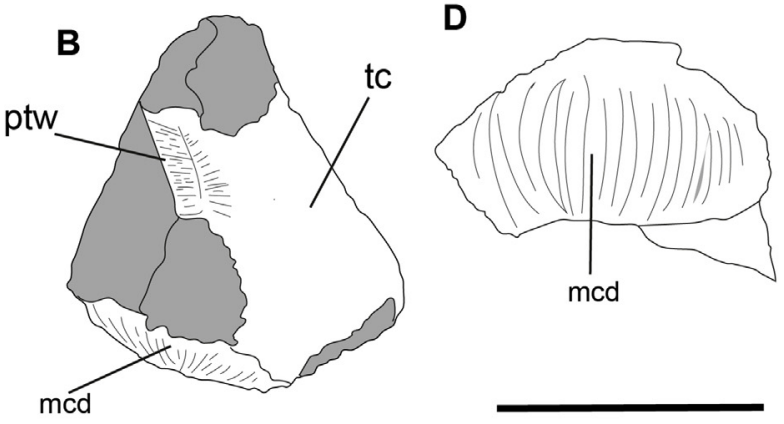

mcd
E

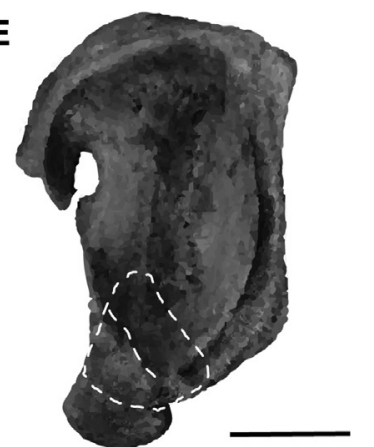

$\mathbf{F}$

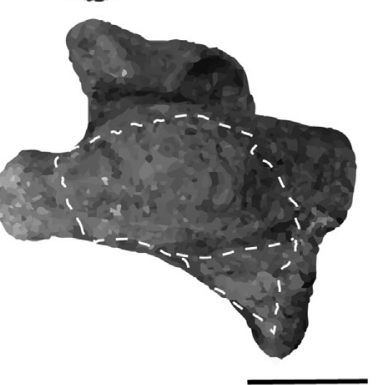

G
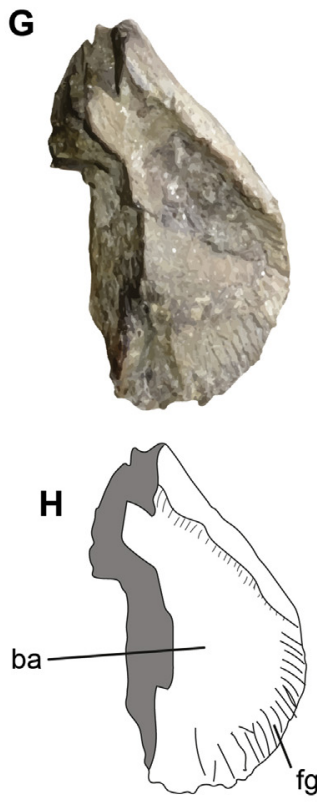

Broken surface

Sediments

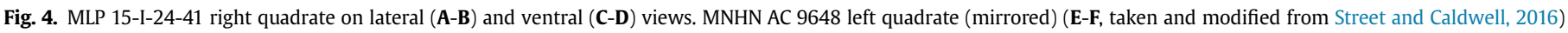

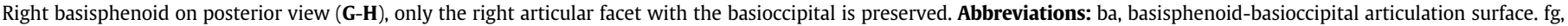
fibrous grooves. mcd, mandibular condyle. ptw, posterior tympanic wall. tc, tympanic conch. Scale bars $=5 \mathrm{~cm}$.

Ventrally the parietal is longitudinally concave. Anteriorly the parietal has a complex articulation with the frontal. Laterally the parietal wings embrace the frontal and bend anteriorly articulating with the posterior and ventral surface of the postorbitofrontal which overlaps the frontal ventrally.

Quadrate. (Fig. 4A-D) Only the articular condyle of the right quadrate and the ventral portion of the tympanic ala are preserved (Fig. 4A-B), the medial surface is covered by sediment and other elements preventing observation of this surface. The articular condyle is convex and has a fusiform shape on ventral view (Fig. 4CD). There is a groove on the edge of the tympanic ala that almost reaches the condyle that seems to be caused by breakage. The overall morphology of the quadrate closely agrees to that of the ventral region of MNHN AC 9648 left quadrate (fig. 4E-F, Street and Caldwell, 2016, fig 13 a, f), however, MLP 15-I-24-41 articular condyle is relatively shorter.

Basisphenoid. (Fig. 4G-H) Only the posterior region and an isolated fragment are preserved. The right articular lobule is preserved on its outmost lateral portion. The fragmentary element is interpreted as a medio-lateral portion of the right basisphenoid.

The right articular surface with the basioccipital is preserved. The articular lobule has a flabelliform shape with a slight concavity. Marginally the surface is covered by fine striations which are deeper and larger on the distal ventral region of the element. The hypothesis that these striations could be joint points with cartilaginous elements or pits to articular protuberances of the basioccipital has been proposed by Street and Caldwell (2016, p. 13 and fig. 10b).

Surangular. (Fig. 5A-D) An incomplete right surangular is preserved on its posteroventral region, both internal and external surfaces are exposed, although the dorsal portion is covered by rock matrix (external surface), or by the superposition of another unknown element (internal surface).
The surangular is a roughly triangular shaped bone that composes the posterolateral end of the mandible on most of the postdentary unit. The dorsal and posterior surfaces are covered by sediments that could not be removed and most of the anteroventral region is not preserved. The lateral surface of the surangular (Fig. 5A-B) is convex while the medial one is slightly concave (Fig. 5C-D). The posterior surangular foramen can be recognized on the lateral wall close to the posterior and dorsal margin of the element, whereas the anterior one is not preserved.

The surangular forms the lateral wall of the glenoid fossa, this fossa forms a canal that runs from the posterodorsal margin of the surangular to the anterior end of this element. Ventrally the surangular is almost straight, the posterior end is the only region where it curves gently outwards.

Angular. (Fig. 6A-B) The right angular is incomplete and only exposed in medial view. The anteroventral region is preserved including the articulation joint with the splenial. The posterior region is not preserved. Ventrally, the angular is straight. The dorsal margin of the angular is oblique, being inclined towards the posterior end of the bone forming an angle close to $40^{\circ}$. The articulation with the splenial is a convex surface that forms a condyle that is indented by a medial notch on the dorsal margin.

Splenial. (Fig. 6C-D) A sheet of bone is found close to the angular. It is interpreted as part of the lateral region of the splenial. A groove runs through the ventral surface of the lateral face of the splenial. Part of the medial wing seems to be preserved but since is covered by sediments is hard to measure how much of it is present.

Coronoid. (Fig. 6E-F) The right coronoid is found partially preserved. The best-preserved portion is the dorsal margin including the proximal segment of the ascending process of the coronoid. This process gives the signature anterolateral concave shape to the coronoid. Medially a groove runs on the lateral side 

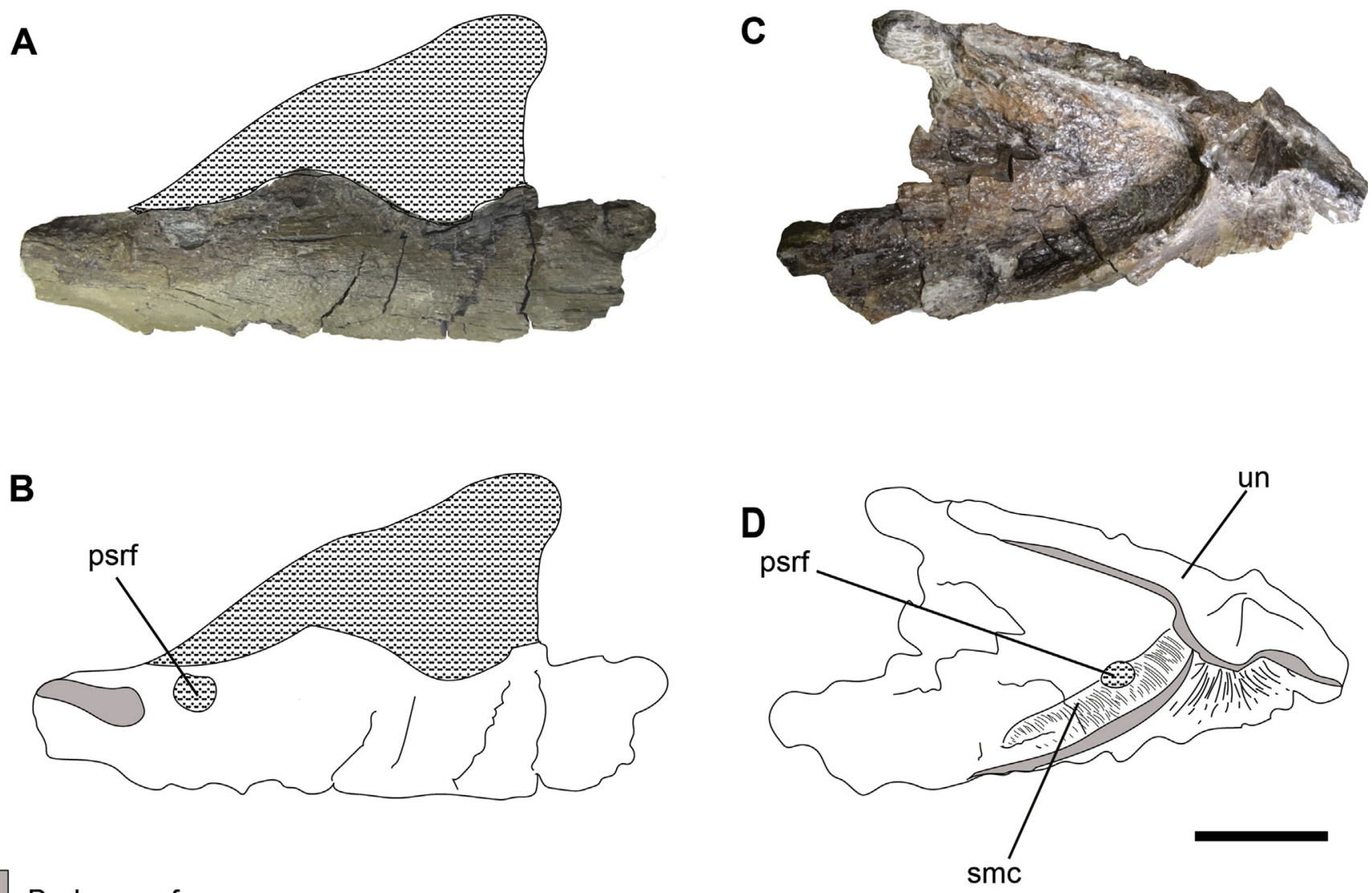

Broken surface

\section{Sediments}

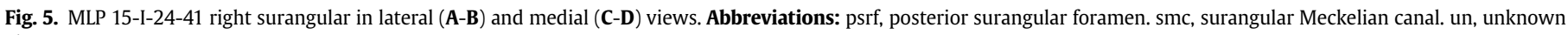
element.

of the ascending process of the coronoid. This groove then becomes a fossa on the lateral side of the coronoid. In cross-section the coronoid has a saddle-like shape. This saddle-like shape is given due to the bending of the lateral and medial wings of the coronoid which surrounds the articulation point for the surangular.

Teeth considerations. Most of the teeth were found in close proximity to the rest of the elements. However, only one pterygoid tooth was found in contact with the cranial elements. It could be that some of the teeth do not correspond with this specimen, but they are similar enough to be considered and grouped together with this specimen.

Marginal dentition. (Fig. 6G-H) One of the recovered teeth can be assigned as a marginal one. The labial surface is the only region preserved. The tooth is slightly curved distolingually. The enamel is smooth and has at least three facets. No carinae are preserved.

Pterygoid teeth. Five small teeth (close to $2 \mathrm{~cm}$ ) (Fig. 6I-L) where recovered. At the base, they have a circular to oval cross section (aspect ratio between 0.8 and 0.5 ). Most of the teeth are curved and robust distolingually on its central region (Fig.6I-J), but some are thinner and have a more triangular outline (Fig. 6K-L). The enamel shows fine striations that run throughout the crown. The labial surface is bulkier than the lingual one which is almost completely flat. The preserved carinae are smooth and do not have any serrations.

\section{Remarks}

\subsection{On the affinities of the MLP 15-I-24-41 specimen}

A large number of species have been referred to the genus Mosasaurus since it was proposed. However, subsequent studies many of such species have been found to be junior synonyms or to belong to other mosasaur genera (Rusell, 1967; Bardet, 1990; Mulder, 1999; Lindgren and Siverson, 2002; Lindgren, 2005; Street and Caldwell, 2016). Rusell (1967) provided the first detailed diagnosis of the genus and reduced it to eight valid species. However, Rusell (1967) based his diagnosis on the comparative and descriptive study of only North American taxa.

Street and Caldwell (2016) revised the type species Mosasaurus hoffmannii and also reviewed the genus Mosasaurus as a whole. As a result of their review ten species are now considered as valid, M. hoffmannii Mantell (1829), M. mokoroa, Welles and Gregg (1971), M. missouriensis, Harlan (1834), M. conodon, Cope (1881), M. lemonnieri, Dollo (1889), M. beauguei, Arambourg (1952), M. dekayi, Bronn (1838), M. hobetsuensis, Suzuki (1985), M. flemingi Wiffen (1990a) and M. prismaticus, Sakurai, Chitoku and Shibuya (1999).

Only one diagnostic feature of Mosasaurus sensu Street and Caldwell (2016) has been preserved on MLP 15-I-24-41 and allows its identification on a generic level: the presence of 


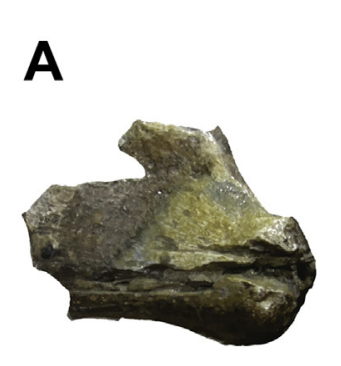

C
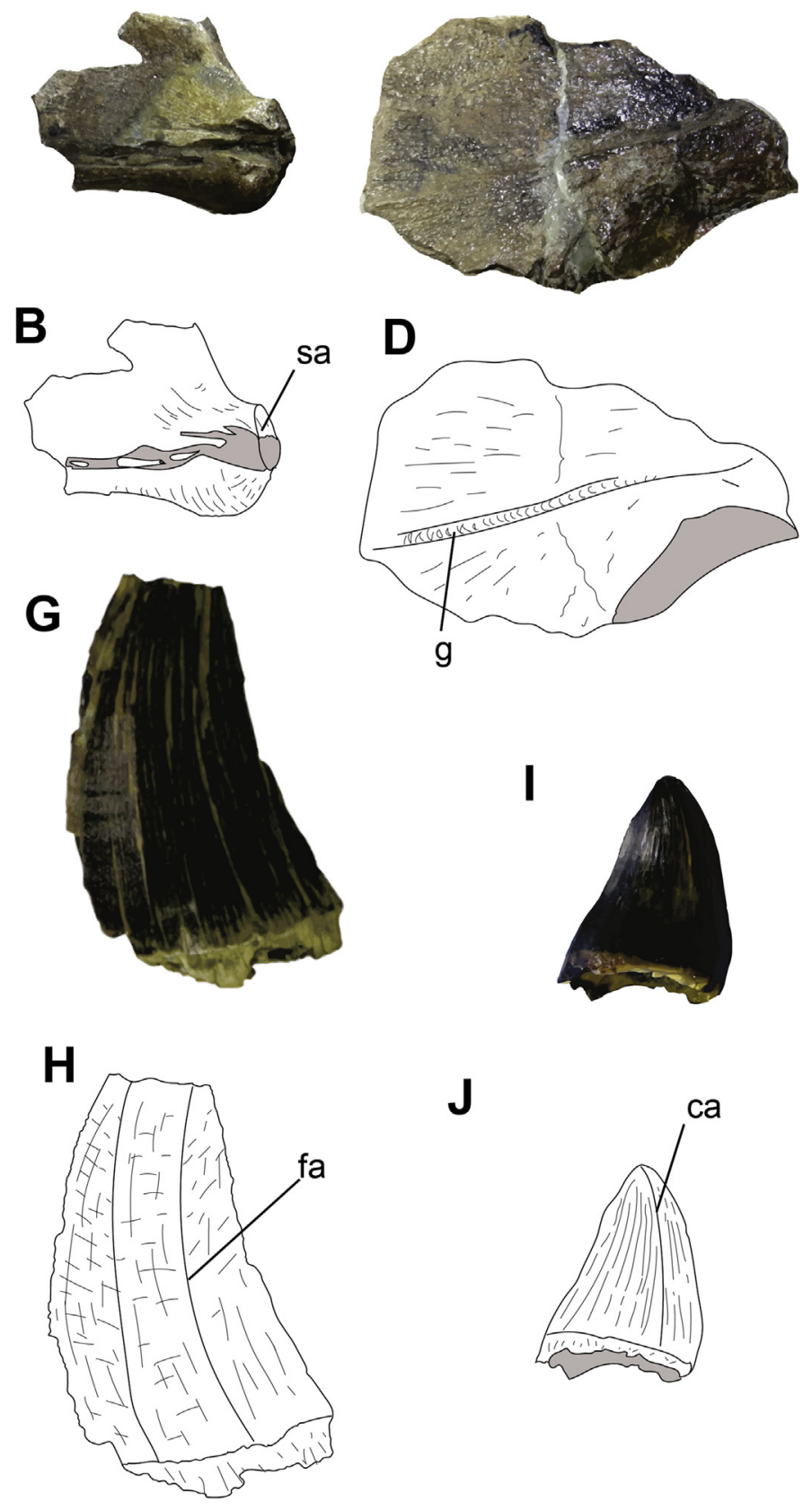

E
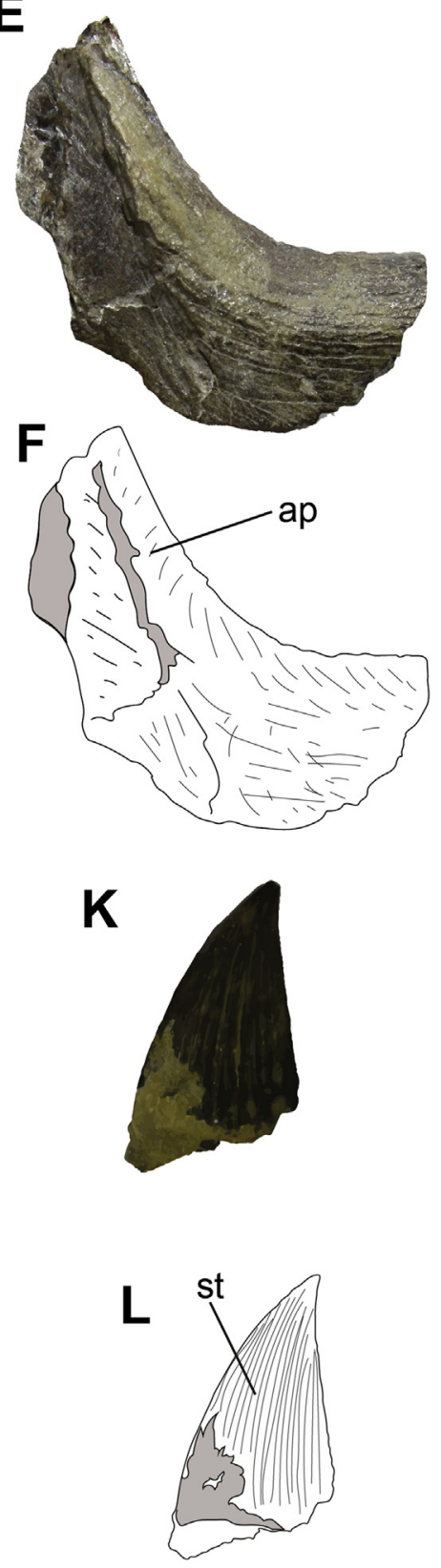

\section{Broken surface}

\section{Sediments}

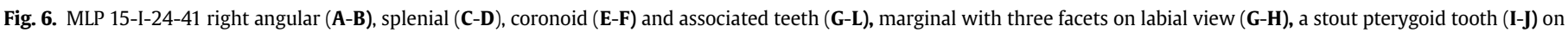

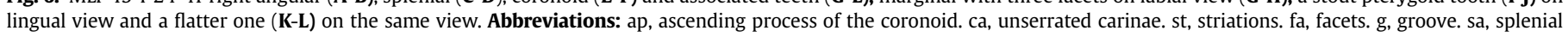
articulation surface of the angular. Scale bar $=5 \mathrm{~cm}(\mathbf{A}-\mathbf{F})=2 \mathrm{~cm}(\mathbf{G}-\mathbf{L})$.

posteromedial processes of the frontal invading deeply the parietal embracing the parietal foramen.

Comparisons within the genus proved to be more difficult because many of the species considered as valid by Street and
Caldwell (2016), particularly those of the Pacific rim, are poorly known or need revision.

One trait that is consistent with three Mosasaurus species is the overall morphology of the recovered marginal tooth, which allows 
comparison with teeth from other plotosaurine mosasaurs. The ornamentation of the crown in the marginal teeth shows facets, this feature is shared by $M$. hoffmannii, M. prismaticus and M. beauguei (Sakurai et al., 1999; Bardet et al., 2004; Street and Calwell, 2016), whereas is lacking in M. conodon and M. mokoroa and is reduced in $M$. hobetsuensis. M. dekayi teeth closely agree with those of M. hoffmannii, however, Street and Caldwell (2016) argue that this species could be considered for reassignment in the future. But assignations based on teeth are problematic, in particular to Antarctic specimens because of the tylosaurine mosasaur Kaikaifilu hervei (Otero et al., 2016).

The taxonomic status of Mosasaurus lemonnieri is controversial. This species is recognized as a mosasaur with a striking resemblance to both $M$. hoffmannii and $M$. missouriensis being more gracile and smaller in size. Rusell (1967) proposed M. lemonnieri to be a junior synonym of $M$. conodon, however, this has since been refuted by Lingham-Soliar (2000) and Ikejiri and Lucas (2015). On the other hand, other authors have proposed that M. lemonnieri represents juveniles of $M$. hoffmannii (Mulder et al., 2004, as cited in; Jagt, 2005) since most of the differences that differentiate them are only appreciated in ideal cases and seems to be ontogenetically variable. However, one feature that differentiates both species is the fact that M. lemonnieri has fluted tooth instead of faceted ones, so, until more conclusive evidence is found to support the synonimy of both taxa, M. lemonnieri remains valid.

Mosasaurus mokoroa and Moanasaurus mangahouangae Wiffen (1980), are two mosasaurine mosasaurs from the Campanian and Maastrichtian of New Zealand that are of interest for any mosasaurine mosasaur found in Antarctica. M. mokoroa has a series of features that differentiate it from other Mosasaurus species as was highlighted by Street and Caldwell (2016), and is still a valid species but in dire need of revision. The fragmentary nature of the specimen described here prevents further comparisons with M. mokoroa since most of the overlapping elements have the usual Plotosaurini features and diagnostic features are not recognized, however, as said above the marginal teeth are the only thing that differs between this specimen and the species.

Moanasaurus mangahouangae is a more interesting scenario, some mosasaur vertebrae from the upper Maastrichtian levels of the Lopez de Bertodano Fm. have been assigned to the Moanasaurus genus (Martin et al., 2002; Martin, 2006). This is the only record outside New Zealand and it is interesting because it comes from the same levels the specimen herein described belongs. However, Moanasaurus has certain features that cannot be identified in this specimen, the fronto-parietal suture of Moanasaurus is different ventrally from that of Mosasaurus, the ventral surface of the frontal is ridged and fluted for the fluted anterior projections of the postorbital (Wiffen, 1980; 1990b), here we don't see any kind of ridges or flutening in the ventral surface and the portion of the postorbital preserved does not seem to be fluted as is the case in Moanasaurus. So affinities to this taxon are discarded for now. It is however imperative to revise this genus since it seems to have been even more diverse than previously thought (Street, 2017).

As mentioned before, comparisons with the other species are hampered by the preservation state of MLP 15-I-24-41 and by the limited amount of comparative material available. In this context we consider it prudent not to propose a new name for the Antarctic specimen and refer MLP 15-I-24-41 as Mosasaurus sp.

\subsection{Plotosaurini paleogeographic occurrence and history}

Plotosaurini Bell 1997, is a clade that includes at least the genera Mosasaurus and Plotosaurus Camp 1951. The monophyly of the former genus has been challenged in recent studies (LeBlanc et al., 2012; Street, 2017), and some species from Belgium and Japan have been suggested to resemble more Moanasaurus than Mosasaurus (Street, 2017) which could imply than in a posterior revision of such species they might be reassigned to the later genus. The genus Plotosaurus is a mosasaur genus that has only been recovered from the Maastrichtian of the United States. Although some records of Plotosaurus from South America (Frey et al., 2016) and Japan (Obata et al., 1972) have been found, their validity as remains from the genus has been challenged (Caldwell and Konishi, 2007; JimenezHuidobro et al., 2017) and assigned as Halisaurine and Russellosaurine mosasaur remains instead respectively.

For the benefit of the discussion, since Moanasaurus and Mosasaurus share morphological traits typically associated to Plotosaurini, Moanasaurus will be considered as a Plotosaurini even though its phylogenetic position is still unresolved and the genus is need of revision.

Mosasaurus is one of the most common genus of mosasaur during the upper Campanian and Maastrichtian. It seems to have appeared almost suddenly worldwide since there are records of Campanian Mosasaurus species in different continents. During the Campanian, Mosasaurus was already present in Europe (M. lemonnieri Lingham-Soliar, 2000), New Zealand (M. flemingi, M. mokoroa, Welles and Greg, 1971; Wiffen, 1990a), Japan (M. hobetsuensis, M. prismaticus Suzuki, 1985; Sakurai et al., 1999) and North America (Russell, 1967). There is a record from the Santonian beds of the Umzamba Formation of South Africa assigned to Mosasaurus sp., (Rogers and Schwarz, 1902), however its validity as such under more recent diagnosis frameworks is still to be determined and it has never been regarded again since the original publication. This Santonian record will not be considered for this discussion since it is confusing, and addressing the date it was published it probably represent a specimen assigned to Mosasaurus when there was not a strong diagnosis for comparison with the genus (which was latter provided by Russell, 1967, with all the problems it had as was highlighted by Street and Caldwell, 2016).

Plotosaurini has a wide distribution in the Late Campanian, represented only by the Mosasaurus genus. Its closest relatives (under recent phylogenetic frameworks, Jiménez-Huidobro and Caldwell, 2016; Madzia and Cau, 2017), Globidensini, Plesiotylsaurus crassidens Camp (1942) and Eremiasaurus heterodontus LeBlanc et al., (2012), have been recorded since the Campanian with a wide distribution as well, the latter two are from the Maastrichtian of North America and Morocco. This would mean that during the Campanian, or even before then, the lineages of Plotosaurini and Globidensini would have had to already started to disperse and diversify to account for the diversity and occurrence of both groups in Upper Campanian strata.

The next closely related taxa are assigned to the Clidastes genus, that is not recovered as monophyletic in modern phylogenetic frameworks (Jiménez-Huidobro and Caldwell, 2016; Madzia and Cau, 2017). The species assigned to the Clidastes genus is known from the Coniacian of North America (Everhart, 2001) up to the Campanian where it can be found in both North America and Europe (Russell, 1967; Lindgren and Siverson, 2004, Fig.7A, B). It is noteworthy that Clidastes seems to have a pattern of dispersal during the Coniacian-Campanian eastward that partially resembles the original distribution of Plotosaurini during the Campanian, being present both in North America and Europe, however, this cannot explain the Campanian distribution of Plotosaurini since it does not account for the Mosasaurus species from Japan and New Zealand. What is more plausible is that the ghost lineages of both Globidensini and Plotosaurini would have originated somewhere in North America and used the same routes of dispersal that the Clidastes used eastward, and would have also found some kind of route westward to explain the Campanian Pacific occurrence of Plotosaurini. 


\section{A. Coniacian-Santonian}

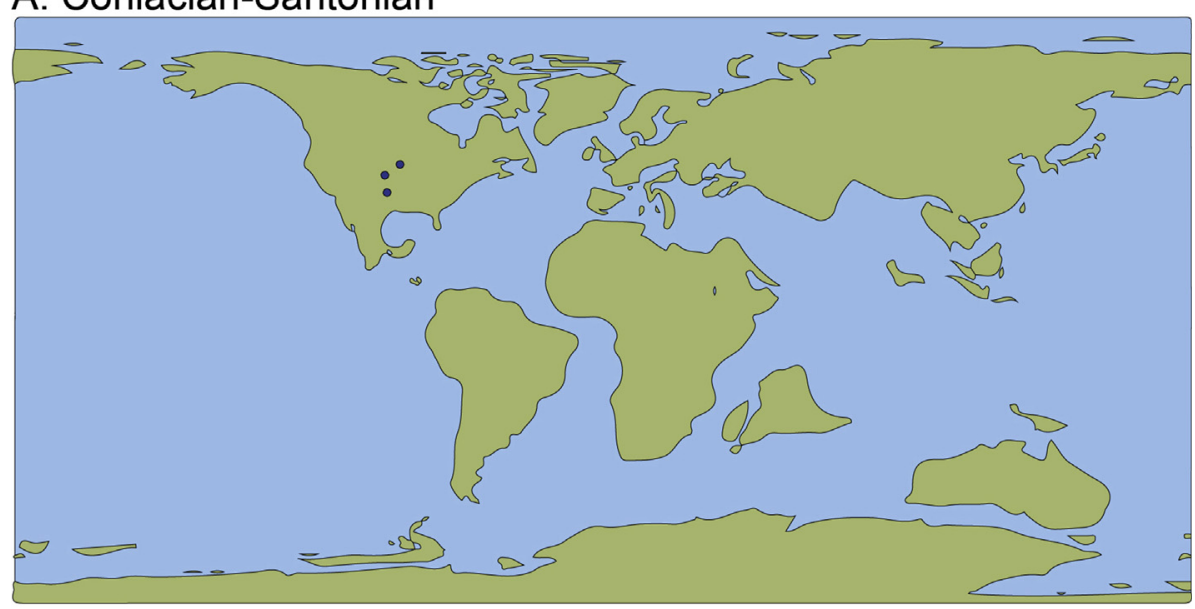

\section{B. Campanian}

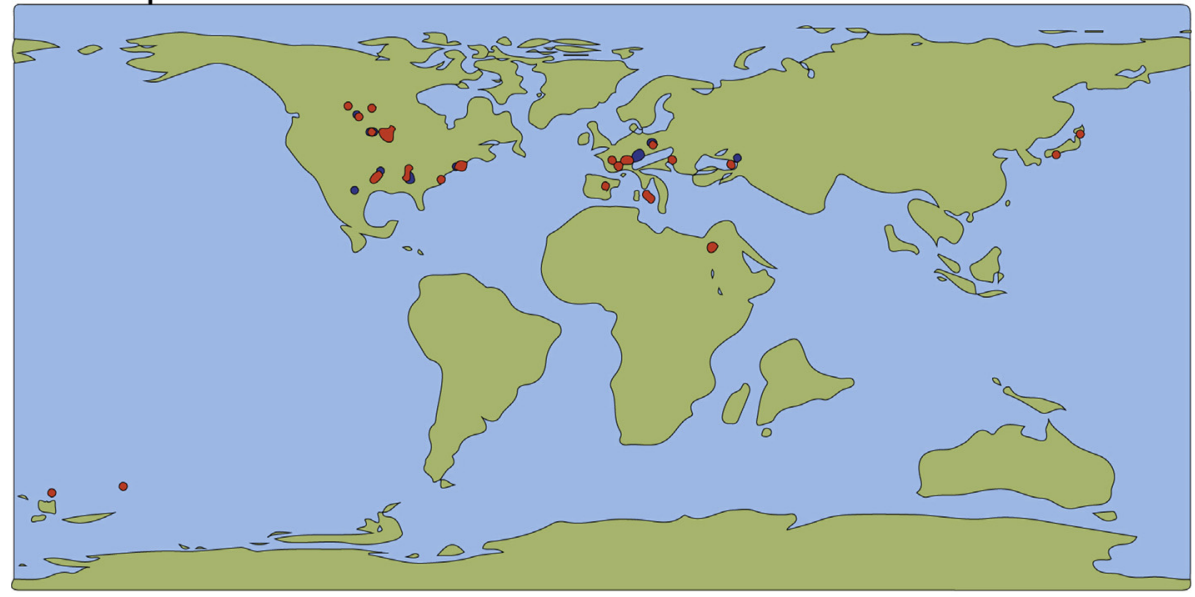

\section{Maastrichtian}

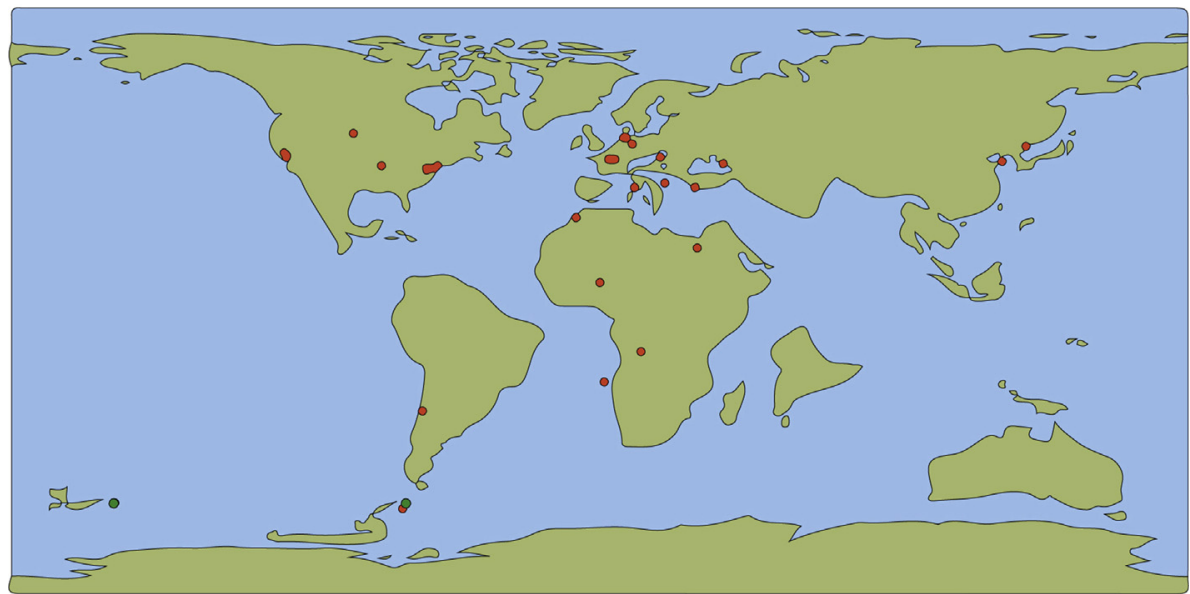

Clidastes

Mosasaurus

Moanasaurus

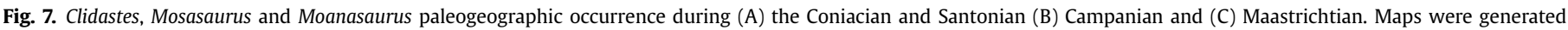
using the mapast package for R (Varela and Sonja Rothkugel, 2018). 
During the Maastrichtian the distribution of Plotosaurini seems to extend southward from their Campanian locations both in the Atlantic and Pacific with records from Angola (Mateus et al., 2012), Democratic Republic of Congo (Lingham-Soliar, 1994), Niger (Lingham-Soliar, 1991), Argentina (Fernández et al., 2008) and Antactica (Martín et al., 2002; Martin, 2006; Martin and Crame, 2006). At the end of the Maastrichtian the tribe has a worldwide distribution (Fig 7C).

This scenario is interesting under the recently raised taxonomic uncertainties of certain species assigned to Mosasurus (Street, 2017) and the possibility that those species could represent members of the Moanasaurus genus instead. If this is the case, we should expect that Campanian species of Mosasaurus from the Pacific Rim to be more closely related between them and with Moanasaurus than to species of Mosasurus from Europe and Africa. Whereas North American species would be expected to be related to either of both groups. In the Maastrichtian these lineages expanded southward as is the only explanation for their Maastrichtian occurrence. The specimens that Street (2017) suspects might be Moanasaurus from Belgium could represent a posterior dispersion event from the Pacific to the Mediterranean.

The Antarctic Plotosaurini remains then should have either a Pacific or Atlantic identity. Some remains from the upper levels of the Lopez de Bertodano Fm. have been assigned as Moanasaurus sp. by Martin et al. (2002), which would support Pacific affinities in the Antarctic Plotosaurini faunas. However, there are uncertainties and an Atlantic affinity cannot be ruled out since most of the Antarctic Plotosaurini remains are fragmentary and their taxonomy, problematic. To solve this issue, a taxonomic and phylogenetic revision of the pacific rim Mosasaurus and Moanasaurus is needed. Until these problems have been addressed the specimen herein described will be assigned as Mosasaurus sp.

\section{Conclusions}

MLP 15-I-24-41 is identified as Mosasaurus sp. based on the anatomy of traits such as the fronto-parietal suture, quadrate and teeth morphology. Some features of northern Patagonia and Antarctic materials allow hypothesizing that they may correspond to a new species. However, no new names are proposed for these specimens as the fossil record is still very incomplete, and the increase of scientific names based on incomplete and/or poorly known or dubious records will hamper (instead of improve) the resolution of the controversial remaining topics on austral mosasaurs. It could however be reassigned in the future to Moanasaurus sp. if the uncertainties surrounding Pacific Rim mosasaurus get clarified.

\section{Acknowledgments}

We would like to thank the Museo de la Plata director, the Dr. Silvia Ametrano for providing the working facilities for this study. We would also like to thank Dr. Eduardo Tonni for allowing access to the materials. We thank Juan José Moly, Leonel Gustavo Acosta and Francisco Solari Orellana for their work as technicians during the fossil preparation stages. We also thank the anonymous reviewers of this work for their insightful comments and observations that helped to greatly improve the manuscript and raised interesting discussion points. We thank Marcelo de la Fuente for all his help during the preparation of the manuscript. And we thank Ana Rivadero for helping with the language proofing of the original manuscript This work was partially supported by Agencia Nacional de Promoción Científica y Tecnológica (PICTs 2016-1039, 20160607) Universidad Nacional de Río Negro (PI-UNRN 40-A-660). This is JML's R-273 contribution to the Instituto de Estudios Andinos Don Pablo Groeber.

\section{References}

Arambourg, C., 1952. Les vertébrés fossiles des gisements de phosphates (Maroc Algérie - Tunisie). Notes et Mémoires du Service Géologique du Maroc 92, $1-372$.

Askin, R.A., 1989. Endemism and heterochroneity in the Late Cretaceous (Campanian) to Paleocene palynofloras of Marambio Island, Antarctica: implications for origins, dispersal and paleoclimates of southern floras. In: Crame, J.A. (Ed.), Origins and Evolution of the Antarctic Biota. Geological Society (London), pp. 107-119 special publication 47.

Bardet, N., 1990. Première mention du genre Hainosaurus (Squamata, Mosasauridae) en France. Comptes Rendus de l’Académie des Sciences, Série II 311 $751-756$.

Bardet, N., Suberbiola, X.P., Iarochene, M., Bouyahyaoui, F., Bouya, B., Amaghzaz, M., 2004. Mosasaurus beaugei Arambourg, 1952 (Squamata, Mosasauridae) from the late Cretaceous phosphates of Morocco. Geobios 37, 315-324.

Bardet, N., Falconnet, J., Fischer, V., Houssaye, A., Jouve, S., Pereda Suber-biola, X. Perez-Garcia, A., Rage, J.C., Vincent, P., 2014. Mesozoic marine palaeobiogeography in response to drifting plate. Gondwana Research 26, 869-887.

Bell Jr., G.L., 1997. A phylogenetic revision of North American and Adriatic mosasaurs. In: Ancient Marine Reptiles. Academic Press, San Diego, pp. 293-332.

Bronn, H.G., 1838. Lethaea Geognostica. Erster Band. E. Schweizerbart's Verlagshandlung, Stuttgart, p. 768.

Caldwell, M.W., Konishi, T., 2007. Taxonomic re-assignment of the first-known mosasaur specimen from Japan, and a discussion of circum-pacific mosasaur paleobiogeography. Journal of Vertebrate Paleontology 272, 517-520.

Camp, C.L., 1942. California mosasaurs. Memoirs of the University of California 13, $1-68$.

Camp, C.L., 1951. Plotosaurus, a new generic name for Kolposaurus Camp, preoccupied. Journal of Paleontology, 822-822.

Conybeare, W.D., 1822. Mosasaurus. The saurus of the Meuse, the Maestricht animal of Cuvier. In: Parkinson, J. (Ed.), An introduction to the Study of Fossil Organic Remains. Sherwood, Neely and Jones, and W. Phillips, London, p. 298.

Cope, E.D., 1881. A new Clidastes from New Jersey. The American Naturalist 15, 587-588.

Dollo, L., 1889. Première note sur les mosasaurs de Mesvin. Bulletin de la Société belge de Géologie, de Paléontologie et d'Hydrologie 3, 271-304.

Elliot, D.H., Askin, R.A., Kyte, F.T., Zinsmeister, W.J., 1994. Iridium and dinocysts at the Cretaceous-Tertiary boundary on Seymour Island, Antarctica: implications for the KT event. Geology 22, 675.

Everhart, M.J., 2001. Revisions to the biostratigraphy of the Mosasauridae (Squamata) in the Smoky Hill Chalk member of the Niobrara Chalk (Late Cretaceous) of Kansas. Transactions of the Kansas Academy of Science 104, 59-79.

Fernández, M.S., Gasparini, Z., 2012. Campanian and Maastrichtian mosasaurs from Antarctic Peninsula and Patagonia, Argentina. In: Bardet, N. (Ed.), Troisième congrès sur les Mosasaures, 183 2. Bulletin de la Sociètè Gèologique de France, vol. 183, pp. 93-102.

Fernández, M.S., Talevi, M., 2015. An halisaurine (Squamata: Mosasauridae) from the Late Cretaceous of Patagonia, with a preserved tympanic disc: Insights into the mosasaur middle ear. Comptes Rendus Palevol 14, 483-493.

Fernández, M.S., Martin, J.E., Casadío, S., 2008. Mosasaurs (Reptilia) from the late Maastrichtian (Late Cretaceous) of northern Patagonia (Río Negro, Argentina). Journal of South American Earth Sciences 25, 176-186.

Frey, E., Mulder, E.W., Stinnesbeck, W., Salazar, C., Quinzio-Sinn, L.A.H., 2016 A mosasaur, cf. Plotosaurus, from the upper Maastrichtian Quiriquina Formation in Central Chile. Cretaceous Research 61, 17-25.

Gallagher, W.B., 2005. Recent mosasaur discoveries from New Jersey and Delaware USA: stratigraphy, taphonomy and implications for mosasaur extinction. Netherlands Journal of Geosciences 84, 241-245.

Gasparini, Z., Del Valle, R., 1980. Mosasaurios: primer hallazgo en el Continente Antártico. Antártica 11, 16-20.

Gasparini, Z., Del Valle, R., 1984. Mosasaurios (Reptilia, Sauria) en el Continente Antártico. IX Congreso Geológico Argentino. S.C. Bariloche, Argentina 4, 423-430.

Gervais, P., 1852. Zoologie et Paléontologie Françaises (Animaux Vertébrés), ou Nouvelles Recherches sur les Animaux Vivants et Fossiles de la France, first ed. Libraire Arthus Bertrand, Paris, p. 271.

Harlan, R., 1834. Notice of the discovery of the remains of the Ichthyosaurus in Missouri, N. A. Transactions of the American Philosophical Society, New Series 4, 405-408.

Huber, B.T., 1988. Upper Campanian-Paleocene foraminifera from the James Ross Island region (Antarctic Peninsula). In: Feldmann, R.M., Woodburne, M.O. (Eds.), Geology and Paleontology of Seymour Island. Geological Society of America, Antarctic Peninsula, pp. 163-252. Memoir Series 169.

Ikejiri, T., Lucas, S.G., 2015. Osteology and taxonomy of Mosasaurus conodon Cope 1881 from the Late Cretaceous of North America. Netherlands Journal of Geosciences 94, 39-54.

Jagt, J.W.M., 2005. Stratigraphic ranges of mosasaurs in Belgium and the Netherlands (Late Cretaceous) and cephalopod-based correlations with North America. Netherlands Journal of Geosciences 84, 283-301. 
Jiménez-Huidobro, P., Caldwell, M.W., 2016. Reassessment and reassignment of the early Maastrichtian mosasaur Hainosaurus bernardi Dollo, 1885, to Tylosaurus Marsh, 1872. Journal of Vertebrate Paleontology 36, e1096275.

Jiménez-Huidobro, P., Otero, R.A., Soto Acuña, S., Caldwell, M.W., 2017. Reevaluación de cf. Plotosaurus del Maastrichtiano superior de Chile, con comentarios sobre la distribución de mosasaurios halisaurinos en Sudamérica. In: Rubilar-Rogers, D. Otero, R.A. (Eds.), I Reunión de Paleontología de Vertebrados. Libro de Resúmenes, Santiago, 28-30 september, 19.

Kiernan, C.R., 2002. Stratigraphic distribution and habitat segregation of mosasaurs in the Upper Cretaceous of western and central Alabama, with an [sic] historica review of Alabama mosasaur discoveries. Journal of Vertebrate Paleontology 22 9-103.

LeBlanc, A.R. Caldwell, M.W. Bardet, N., 2012. A new mosasaurine from the Maastrichtian (Upper Cretaceous) phosphates of Morocco and its implications for mosasaurine systematics. Journal of Vertebrate Paleontology 32, 82-104.

Lindgren, J., 2005. The first record of Hainosaurus (Reptilia: Mosasauridae) from Sweden. Journal of Paleontology 76, 1157-1165.

Lindgren, J., Siverson, M., 2002. Tylosaurus ivoensis: a giant mosasaur from the early Campanian of Sweden. Earth and Environmental Science Transactions of the Royal Society of Edinburgh 93, 73-93.

Lindgren, J., Siverson, M., 2004. The first record of the mosasaur Clidastes from Europe and its palaeogeographical implications. Acta Palaeontologica Polonica 49, 219-234.

Lingham-Soliar, T., 1991. Mosasaurs from the upper Cretaceous of Niger. Palaeontology 34, 653-670

Lingham-Soliar, T., 1994. First record of mosasaurs from the Maastrichtian (Upper Cretaceous) of Zaire. PalZ 68, 259-265.

Lingham-Soliar, T., 2000. The mosasaur Mosasaurus lemonnieri (Lepidosauromorpha, Squamata) from the Upper Cretaceous of Belgium and The Netherlands. Paleontological Journal 34 (Suppl. 1), 225-237.

Linnaeous, C., 1758. Systema Naturae, Secundum Classes,Ordines, Genera, Species, cum Characteribus, Differentiis,Synonymis, Locis. Tomus I. Editio Decima, Reformata. Laurentii Salvii, Stockholm, p. 824.

Macellari, C.E., 1988. Stratigraphy, sedimentology and paleoecology of Upper Cretaceous/Paleocene shelf-deltaic sediments of Seymour Island (Antarctic Peninsula). In: Feldmann, R.M., Woodburne, M.O. (Eds.), Geology and palaeontology of Seymour Island, Antarctic Peninsula. Geological Society of America, pp. 25-53. Memoir, 169 .

Madzia, D., Cau, A., 2017. Inferring 'weak spots' in phylogenetic trees: application to mosasauroid nomenclature. PeerJ 5 e3782. https://doi.org/10.7717/peerj.3782.

Mantell, G.A. 1829. A tabular arrangement of the organic remains of the county of Sussex. Transactions of the Geological Society, Second Series 3, 201-216.

Martin, J.E., 2006. Biostratigraphy of the Mosasauridae (Reptilia) from the Cretaceous of Antarctica. Special Publication - Geological Society of London 258, $101-108$.

Martin, J.E., Crame, J.A., 2006. Palaeobiological significance of high-latitude Late Cretaceous vertebrate fossils from the James Ross basin, Antarctica. In: Pirrie, J.E. Crame, J.A. (Eds.), Cretaceous-Tertiary high-latitude palaeoenvironments, James Ross basin, Antarctica, vol. 258. Geological Society Special Publications, pp. 109-124, 97.

Martin, J.E., Bell Jr., G.L., Case, J.A., Fernández, M.S., Gasparini, Z., Reguero, M. Woodburne, M.O., 2002. Late Cretaceous mosasaurs (Reptilia) from the Antarctic Peninsula. Royal Society of New Zealand Bulletin 35, 293-299.

Mateus, O., Polcyn, M.J., Jacobs, L.L., Araújo, R., Schulp, A.S., Marinheiro, J., Pereira, B. Vineyard, D., 2012. Cretaceous amniotes from Angola: Dinosaurs, Pterosaurs, Mosasaurs, Plesiosaurs and Turtles. Acta Paleontologica Polonica 54, 581-588.

Milàn, J., Jagt, J.W., Lindgren, J., Schulp, A.S., 2017. First record of Carinodens (Squamata, Mosasauridae) from the uppermost Maastrichtian of Stevns Klint, Denmark. Alcheringa. An Australasian Journal of Palaeontology 1-6.

Mulder, E.W.A., 1999. Transatlantic latest Cretaceous mosasaurs (Reptilia, Lacertilia) from the Maastrichtian type area and New Jersey. Geologie en Mijnbouw 78, $281-300$.

Mulder, E.W.A., Coernelissen, D., Verding, L., 2004. Is Mosasaurus lemonnieri a juvenile Mosasaurus hoffmannii? A discussion. In: Schulp, A.S., Jagt, J.W.M. (Eds.), First Mosasaur Meeting, Maastricht, 8-12 May, Abstract book and field guide, pp. 62-66.

Mulder, E.W.A., Jagt, J.W.M., Kuypers, M.M.M., Peeters, H.H.G., Rompen, P., 1998 Preliminary observations on the stratigraphic distribution of Late Cretaceous marine and terrestrial reptiles from the Maastrichtian type area (SE Netherlands, NE Belgium). Oryctos 1, 55-64.

Obata, I., Hasegawa, Y., Otsuka, H., 1972. Preliminary report on theCretaceous reptile fossils from Hokkaido. Bulletin of the National Science Museum 5, 213-222.

O'Gorman, J.P., Panzeri, K.M., Fernández, M.S., Santillana, S., Moly, J.J., Reguero, M. 2017. A new elasmosaurid from the upper Maastrichtian López de Bertodano Formation: new data on weddellonectian diversity. Alcheringa: An Australasian Journal of Palaeontology 1-12.
Olivero, E.B., 2012. Sedimentary cycles, ammonite diversity and palaeoenvironmental changes in the Upper Cretaceous Marambio Group, Antarctica. Cretaceous Research 34, 348-366.

Olivero, E.B., Ponce, J.J., Martinioni, D.R., 2008. Sedimentology and architecture of sharp-based tidal sandstones in the upper Marambio Group, Maastrichtian of Antarctica. Sedimentary Geology 210, 11-26.

Oppel, M., 1811. Die Ordnungen, Familien, und Gattungen der Reptilien als Prodrom Einer Naturgeschichte Derselben. Joseph Lindauer, Munich, p. 86.

Otero, R.A., Soto-Acuña, S., Rubilar-Rogers, D., Gutstein, C.S., 2016. Kaikaifilu hervei gen. et sp. nov., a new large mosasaur (Squamata, Mosasauridae) from the Upper Maastrichtian of Antartica. Cretaceus Research 70, 209-225.

Polcyn, M.J., Tchernov, E., Jacobs, L.L., 1999. The Cretaceous biogeography of the eastern Mediterranean with a description of a new basal mosasauroid from 'Ein Yabrud, Israel. In: Tomida, T., Rich, T., Vickers-Rich, P. (Eds.), Proceedings of the Second Gondwanan Dinosaur Symposium, vol. 15. National Science Museum Tokyo, Monographs, pp. 259-290.

Polcyn, M.J., Tchernov, E., Jacobs, L.L., 2003. Haasiasaurus gen. nov., a new generic name for the basal mosasauroid Haasia Polcyn et al., 1999. Journal of Vertebrate Paleontology 23, 476.

Polcyn, M.J., Jacobs, L.L., Araújo, R., Schulp, A.S., Mateus, O., 2014. Physical drivers of mosasaur evolution. Palaeogeography, Palaeoclimatology, Palaeoecology 400, $17-27$.

Rinaldi, C.A., Massabie, A., Morelli, J., Rosenman, H.L., Del Valle, R.A., 1978, Geología de la isla Vicecomodoro Marambio. Instituto Antártico Argentino, pp. 1-44 contribución 217.

Rogers, A.W., Schwarz, E.H.L., 1902. General survey of the rocks in the southern parts of the Transkei and Pondoland, including a description of the Cretaceous rocks of eastern Pondoland. Annual Report of the Geological Commission, Cape of Good Hope 1901, 25-46.

Russell, D.A., 1967. Systematics and morphology of American mosasaurs. Bulletin Peabody Museum of Natural History 23, 241.

Sakurai, K., Chitoku, T., Shibuya, N., 1999. A new species of Mosasaurus (Reptilia, Mosasauridae) from Hobetsu, Hokkaido, Japan. Bulletin of the Hobetsu Museum 15, 53-66.

Street, H.P., 2017. Reassessing Mosasaurini based on a systematic revision of Mosasaurus. In: Murray, A.M., Holmes, R.B. (Eds.), 5th Annual Meeting Canadian Society of Vertebrate Palaeontology, Alberta, 15-17 May, Abstract and field guide, p. 42.

Street, H.P., Caldwell, M.W., 2016. Rediagnosis and redescripion of Mosasaurus hoffmannii (Squamata: Mosasauridae) and an assessment of species assigned to the genus Mosasaurus. Geological Magazine Cambridge University Press, pp. 1-37.

Suzuki, S., 1985. A new species of Mosasaurus (Reptilia, Squamata) from the Upper Cretaceous Hakobuchi Group in CentralHokkaido, Japan. In: Goto, M., Takahashi, M., Kimura, M., Horikawa, H. (Eds.), Evolution and Adaptation of Marine Vertebrates. Association for Geological Collaboration in Japan, pp. 45-66. Monograph no. 30.

Varela, S., Sonja Rothkugel, K., 2018. mapast: combine paleogeography and paleobiodiversity. R package version 0.1. https:/github.com/macroecology/mapast.

Welles, S.P., Gregg, D.R., 1971. Late Cretaceous marine reptiles of New Zealand. Records of the Canterbury Museum 9, 1-111.

Wiffen, J., 1980. Moanasaurus, a new genus of marine reptile (Family Mosasauridae) from the Upper Cretaceous of North Island, New Zealand. New Zealand Journal of Geology and Geophysics 23, 507-528.

Wiffen, J., 1990a. New mosasaurs (Reptilia; Family Mosasauridae) from the Upper Cretaceous of North Island New Zealand. New Zealand Journal of Geology and Geophysics 33, 67-85.

Wiffen, J., 1990b. Moanasaurus mangahouangae or Mosasaurus mangahouangae. New Zealand Journal of Geology and Geophysics 33, 87-88.

Zinsmeister, W.J., 1979. Biogeographic significance of the Late Mesozoic and early Tertiary molluscan faunas of Marambio Island (Antarctic Peninsula) to the final break-up of Gondwanaland. In: Gray, J., Boucot, A.J. (Eds.), Historical Biogeography, Plate Tectonics and the Changing Environment. Oregon State University Press, Corvallis, pp. 349-355.

Zinsmeister, W.J., 1982. Review of the Upper CretaceouseLower Tertiary sequence on Marambio Island, Antarctica. Journal of the Geological Society of London 139, 779-786.

Zinsmeister, W.J., Macellari, C.E., 1988. Bivalvia (Mollusca) from Seymour Island, Antarctic Peninsula. In: Feldmann, R.M., Woodburne, M.O. (Eds.), Geology and palaeontology of Seymour Island, Antarctic Peninsula. Geological Society of America, pp. 253-284. Memoir 169.

\section{Appendix A. Supplementary data}

Supplementary data to this article can be found online at https://doi.org/10, 1016/j.cretres.2019.06.012. 